\title{
Lifelong learning governance and International Organisations
}

Mihaela-Viorica Ruşitoru, IUTAM Montréal

Arto Kallioniemi, University of Helsinki

Alison Taysum, Professional Educational Consultant

Lifelong learning policies are subject to various approaches of educational governance. Our research presents a hypothesis that lifelong learning policies are creating and engaging with new facets of governance. To test for proof of concept, the lead author conducted interviews with officials and policy makers from international organisations such as the United Nations Education, Science and Culture Organisation, the Organisation for Economic Cooperation and Development, the International Labour Organisation and the Council of Europe. The thematic analysis of the data revealed lifelong learning governance is characterised by an "effects spiral» or "interactive governance» - an institutional formation, functioning and conditioning in decision making of international, European and national actors. A double issue is also highlighted: the economic difficulties (employability, flexi-security, funding and mobility) and the monitoring process (expertise, comparison, transposition, supervision and control), which are prioritised over the social role of education. This is important because it is the social role of education that empowers citizens to realise national, regional, and international strategic plans, and the monitoring process for sustainable development. The thematic analysis reveals new forms of governance in lifelong learning policies, namely collaborative governance, competitive governance, control governance and thematic governance. The authors present this taxonomy on lifelong learning governance with recommendations of how lifelong learning policies can be optimised.

\section{Int roduction}

Lifelong learning policies are increasingly being discussed by policy makers, researchers, teachers and parents. They have always been the subject of discussion in almost every country, following endless reforms. International or European organisations have been trying for years to define key elements of common educational policies all over the world and to put problems of education and 
training on their agenda. Researchers in the field of educational and political sciences have examined these current challenges. Theories about the usefulness of supranational governance in education are questioned and discussed by researchers, trainers and trainees at all levels of society. Our research presents a hypothesis that lifelong learning policies are creating and engaging with new facets of governance. To test for proof of concept the lead author conducted interviews with officials and policy makers from international organisations such as the United Nations Education, Science and Culture Organisation, the Organisation for Economic Cooperation and Development, the International Labour Organisation and the Council of Europe. Combining theoretical approaches with research on the ground, the approaches adopted by international officials influencing policies and the examination of the statements and informal assertions with the officials are revealed.

If lifelong learning is a current preoccupation in academic and political circles, the question nonetheless arises, what are the pre-eminent features of governance and administration for lifelong learning policies developed by the International Organisations? To address this question we describe the international lifelong learning policies, the research hypothesis and methods as well as the data analysis and reveal a typology of four forms of educative governance, namely collaborative, competitive, control and thematic governance.

\section{Theoretical framework on international governance on lifelong learning}

Internationally, education remains a complex concept debated by researchers and policy makers. The influence of international organisations on educational policies is increasing within the context of Europeanisation and globalisation (Moreau Defargues, 2000; Nye Jr, 2002; Roche, 2001). Understanding the changing approaches to education presumes that national and supranational policy makers and social actors interact (Broyon, 2001; Dale, 2009; Pépin, 2006). Globalisation versus dissolution of the nation state (Cordellier, 2005; Kissinger, 1996), or advantages versus disadvantages of globalisation (Snyder, 2000) constitute themes which enrich the debate. Linked to education international level, indicators and benchmarks became factors for ensuring performance and quality assurance (Kamens \& McNeely, 2009; Lawn \& Grek, 2012), while education and certification, for example of diplomas, play an important role for the economic growth in nowadays context (Aghion \& Cohen, 2004).

Generally speaking, lifelong learning is defined as: «all learning activities undertaken throughout life, with the aim of improving knowledge, skills and competence, within a personal, civic, social and/or employment-related perspective» (CEDEFOP, 2008, p. 123). In this article, we are inspired by the definition of lifelong learning given by Ruşitoru (2017) as follows:

Lifelong learning represents an intergenerational process through which acqui- 
sition and updating of knowledge, skills, attitudes, behaviours and accomplishments are being developed at all ages and in all dimensions of life. Enabling personal and professional development of each human being, lifelong learning contributes to the integral development of a harmonious and multi-potential personality capable, on the one hand, of mastering their own path to adapt to current and future social expectations and on the other hand, of acquiring fundamental human values - intellectual, moral, professional, social and spiritual. (p. 230)

It is important to mention that there is not one holistic definition but only some ideas to help readers to better understand this educational reality. Concerning lifelong learning, educational policies could be conceived as: «action-centred programmes launched by a public authority, influenced by values and ideas, addressed to a scholar public and implemented by administration and educational professionals» ${ }^{1}$ (Van Zanten \& Rayou, 2011, p. 55).

Educational systems are closely linked to a country's features, its national identity, its culture and tradition, as well as with the different forms of education: formal, non-formal, informal, compulsory or continuous. International organisations may play a role in the implementation of educational policies by means of various approaches: economic or social, cultural or legal, but also by employment or wellbeing related. Consequently, concepts, ideas, measures and programmes concerning education suggested by international organisations are diverse and depend on the particular character of each organisation. Thus,

1. Education helps to come to intercultural understanding and to encourage democratic citizenship in a globalised world - Council of Europe (CoE) (Vorbeck, 1969, $1^{\text {st }}$ July , 1970, 1973);

2. Education represents a right for all focused on six pillars, emphasising the social impact in the access to education, namely learning to know, learning to do, learning to live together, learning to be, learning to change and learning to become, promoting literacy and adult education - United Nations Education, Science and Culture Organisation (UNESCO) (Delors, 1996, 2002; Faure, 1972);

3. Education represents a key element for economic cooperation between states - Organisation for Economic Cooperation and Development (OECD) (OECD, 1997, 2007);

4. Education supports well-being at work and a decent work environment International Labour Organisation (ILO) (ILO, 2004, 2009).

Basically, governance implies a relationship between different educational actors which is defined nowadays in different manners. For instance, in the current literature are evoked multi-level governance, governance in networking and the open method of coordination (Saurugger, 2009); governance by integration and reputation (Boussaguet \& Jacquot, 2009); as well as governance in education between IO and EU (Radaelli, 2010). These different approaches to education 
illustrate the complexity and diversity of lifelong learning policies. Mainly, international and European influence is practiced through legal instruments such as conventions, declarations, resolutions and recommendations. According to this orientation, lifelong learning policies are more or less focused on certain aspects. Thus, relevant influence in the Member States may differ. Theoretically, the forms of governance and management are therefore extremely varied. Discourse with key officials from these organisations will reveal emerging aspects of lifelong learning governance.

\section{Research Hypothesis And Methodology}

Lifelong learning policies currently developed at European and international level have been analysed by researchers mostly focused on the theoretical level. However, a research question argues: Is there a gap between the political discourse and the scientific one concerning the educational management put into practice by the International Organisations?

To complete this approach, interviews with officials and policy makers from international organisations were conducted. This emerging question compelled to the formulation of the research problem as follows:

What are the characteristics of governance on lifelong learning policies deployed by International Organisations?

Following numerous changes at international and European level, globalisation reveals unexpected features of educational governance. Linked to this research problem, our main aim was to highlight the policy makers' discourse concerning the specificity of governance in lifelong learning. This overall aim is divided into several objectives:

1. To complete previous research work by innovative fieldwork;

2. To analyse direct statements of international organisations' officials and policy makers;

3. To compare official discourse with the content of the interviews conducted.

In connection with this issue and based on the research problem as well as the aim and objectives, a research hypothesis was formulated in the following terms: In a context of emerging Europeanisation and globalisation, lifelong learning policies developed by International Organisations show specific forms of educational governance.

This research has an interdisciplinary character, combining educational and political sciences. The choice was made to describe the unfolding of the research, the instrumentation of the research as well as the ethical and deontological issues and finally, the research sampling and the data analysis process.

A variety of methods were used during the research, that is to say, internships 
in different International Organisations aiming at the familiarisation with the political work and at the adaptation of the interview guides and the methodological approach. For the purpose of testing the interview guide, «exploratory interviews» (Tessier, 1993) were conducted. A heuristic stage was accomplished, and this helped to confirm the methodological approach (De Ketele \& Roegiers, 1996). Since the research is built on the qualitative approach, semi-structured interviews (Mucchielli, 1991) with international officials, based on an interview guide, represented the key method.

Concretely, a letter of invitation written in English and French was sent to officials by e-mail. The letter was accompanied by a description of the purpose of the research and the interview guide. Gradually, officials responded favourably to the request and, finally a representative number of officials participated in the sampling. The lead author visited each site in Hamburg, Geneva, Paris and Strasbourg for a prolonged period to conduct face to face interviews. If people agreed, interviews were recorded using a recorder (Kaufmann, 1996). If they preferred, notes without recording were taken. On average, the interviews lasted between 30 and 120 minutes per person. The final step was making the interview contents anonymous and confidential.

Sampling was one of the hardest elements of the research, because international officials are, on the one hand, difficult to access and on the other hand, bound by professional secrecy. Applying the «mock-up principle» and "purposive sampling» defined by Van der Maren (1995), a core sampling was identified with persons who were:

1. Officials involved in the elaboration and implementation of educational policies;

2. Officials including educational analysts or senior consultants who were willing to talk about their work in the scope of the research.

According to the principle of Van der Maren (1995), the most important criterion was the involvement of the officials in the implementation of lifelong learning policies. The almost twenty officials who accepted to be part of the research were: administrators and senior administrators, heads of service and programmes' coordinators, department managers and lawyers, judges and «jurisconsulte». They belonged to one of the four groups from the sample mapped to each of the four governance systems. It was noticed that officials with a high responsibility were more comfortable to participate with the research. Given the fact that the research presented in the article is part of a broader research project, it was not possible to specify separately the number of officials interviewed for each organisation neither for each professional status. As an explanation, the table below (Table 1) compiles the different professional status of officials involved in the research: 
Table 1: Sampling and professional status of international officials interviewed

\begin{tabular}{lll}
\hline & International organisations & Professional statute \\
\hline $1 . \quad$ UNESCO & $\begin{array}{l}\text { Administrator } \\
\text { Expert on educational programmes } \\
\text { Seniors administrator } \\
\text { Head of services }\end{array}$ \\
\hline 2. $\quad$ Council of Europe & $\begin{array}{l}\text { Administrator } \\
\text { Head of service } \\
\text { Lawyer }\end{array}$ \\
& & $\begin{array}{l}\text { Judge } \\
\text { Jurisconsulte }\end{array}$ \\
& & $\begin{array}{l}\text { Administrator } \\
\text { Department Manager } \\
\text { Programme coordinator }\end{array}$ \\
3. International Labour Organisation & & $\begin{array}{l}\text { Head of division } \\
\text { Administrator }\end{array}$ \\
\hline 4. $\quad \begin{array}{l}\text { Organisation for Economic Cooperation } \\
\text { and Development }\end{array}$ &
\end{tabular}

More than twenty international officials accepted to give an interview on lifelong learning policies, after giving their consent to participate in the research and to use their verbatim quotations. After that, in order to ensure data protection, all quotes were anonymised and sections removed to maintain confidentiality so the officials cannot be identified.

The aim of the research was to obtain relevant and original information concerning governance on lifelong learning policies developed by international organisations. For that reason, semi-structured interviews and qualitative methods turned out to be the best methodological choice. The method of semistructured interviews is connected with the analysis of thematic content. This analysis contributed to obtaining useful information and to enlarge the scope of the participants' thoughts (Quivy \& Van Campenhoudt, 2006). Briefly, the content analysis represents «a technique allowing to examine methodologically, systematically, objectively and occasionally, quantitatively the content of certain texts in order to classify and interpret its components, which may not be completely obvious at first sight» (Robert \& Bouillaguet, 1997, p. $4^{2}$ ).

After conducting the interviews, we opted for an in-depth investigation of their content (Déplelteau, 2002; Léssard-Hebert et al., 1997; Van den Maren, 1995). To facilitate the analysis, it was important to «clean», translate and fully transcribe (Albarello, 2003) the 21 interviews selected for the analysis. Thereafter, according to the thematic-unit identified in the interview guide an "analysis grid» of the contents was developed following the models proposed by Guittet (2002), Quivy and Van Campendhout (2006) or Schemeil (2010). The original guide interview with policy makers comprised eight thematic units, such as: lifelong learning, educational policies, European Union and the International Organisations, Romania and the International Organisations, implementation of lifelong learning policies, globalisation of education and legal framework on 
lifelong learning. Nevertheless, for the purpose of this article, only the thematic units focussing on lifelong learning policies and the International Organisations were retained to highlight the interrelationship between lifelong learning policies favoured by international organisations, European and national educational actors and policy makers.

Thus, each unit was subsequently cut into several sub-units. In the first step, a «modelling» approach was used (De Ketele \& Roegiers, 1996), to identify and understand the main variables of each discussed theme. Then, the different models identified were compared (Schemeil, 2010). Finally, after encoding and decoding, the next step was to assemble the scientific corpus and cross data concerning governance on lifelong learning policies in the international context, through a traditional analysis (without software). The data analysis reflects an enormous variety of assertions concerning educational governance. Statements from officials are numbered and identified in the analysis part.

\section{Outcomes on lifelong learning governance}

Globalisation influences each country and each field of activity, including lifelong learning policies. Several changes on educational governance could be identified at national, European or international levels from the analysis. From our analysis, four new forms of governance promoted by the international organisations on lifelong learning policies emerged, namely collaborative governance, competitive governance, control governance and thematic governance.

\section{Collaborative governance}

The discourse concerning educational management and governance on lifelong learning policies developed by international organisations is dynamic. Lifelong learning seems to be an initiative proposed, more or less, at the European and international level in order to respond to economical challenges. In this respect: «lifelong learning was initially a matter of fighting against unemployment, a kind of labour market flexibility helping people who lost a job in one field to more easily find a job in other field, (Interview 4). Actually, the global challenge in education remains principally connected to economic issues (European Union, 2003; Snyder, 2000). In order to meet the objectives proposed at global level, international organisations cooperate and aim at influencing national policy makers. Educational governance is focused on the identification of common issues. Joint activities are the successful key for lifelong learning policies. In this way, one interlocutor explains the specificity of teamwork where policy makers from different international organisations are involved in education: «We are sharing the work, because there are opportunities to work together on such projects. For example, with the Organisation for Economic Cooperation and Development, we are finding indicators in education. With the European Union, there are a lot of projects 
and we cooperate especially in adult education, in the Grundtvig programme. We also invite the Council of Europe and all international organisations to participate in our conferences» (Interview 17). The findings in educational management connect with «multi-level governance» (Saurugger, 2009), given that there is some institutional imitation. It seems that there is a "collaborative governance» or «egalitarian governance», given that there is a process involving the actions of several international organisations acting mutually as well as on an equal footing. Thus, collaborative governance includes joint activities which aim at adapting educational offers to the labour market. The figure bellow reflects the main characteristics of collaborative or egalitarian governance on lifelong learning policies:

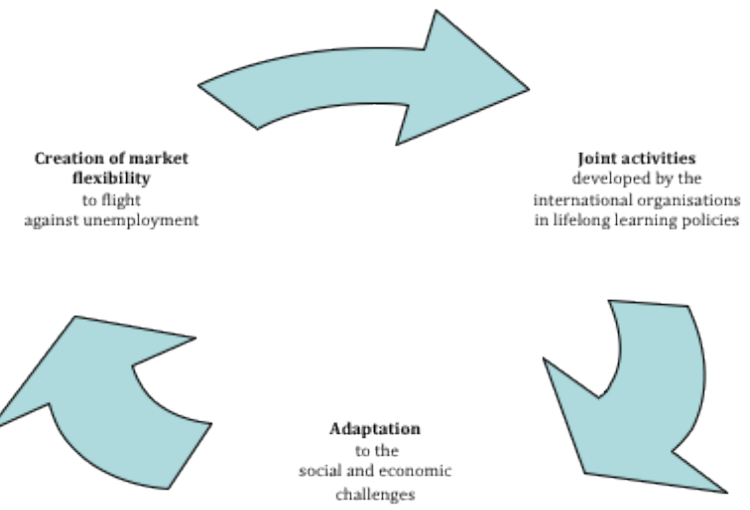

Figure 1: Main characteristics of "collaborative or egalitarian governance» on lifelong learning policies

\section{Competitive governance}

Other officials interviewed shared a different point of view concerning international cooperation in education. Common participation in conferences and mutual working visits cannot be qualified as a strong common effort in favour of lifelong learning policies. Global orientations of international organisations are quite different and consequently, speaking about: "cooperation is a bit too much. At the moment, we visited each other, and we informed each other about meetings. But cooperation in a structural sense did not exist. The only institutionalised and formalised cooperation was the biannual conferences" (Interview 21). It seems that policy makers and educational actors need more than one biannual conference to understand more deeply what can enhance education outcomes as well as wellbeing for sustainable economic and social growth for delivering appropriate strategies. International organisations do not seem to be in the same position. Mutual inspiration or competition can be observed at an international level (Dale, 2009; Radaelli, 2010). For instance, even if the European Union appeared 
later on the global educational arena, its influence is more visible: «I believe that the European Union was deeply inspired by the work of United Nations Education, Science and Culture Organisation, as well as by the Organisation for Economic Cooperation and Development, but ... also the others found a great inspiration in the European Union» (Interview 18). Apart from this mutual inspiration, the European Union remains for the other international organisations an example of regionalised governance in lifelong learning policies. If: «Europeanisation was considered a regionalisation and European Union is already a global region" (Interview 11), international governance could replace national responsibility on education. At the beginning, the European Economic Community wanted to create a common market in order to ensure free movement of goods, services, capitals and also the mobility of people and exchange of educational ideas. As a supranational actor, the European Union continues to stress its economic priorities while raising education to the rank of a pillar for its economic and social strategy (European Union, 2009; Pépin, 2006). Consequently, for the other international organisations, the European Union represents a source of inspiration and a model. In reality: "For Africa, Asia and the Arab states there is not one organisation, not even a common policy, while it exists in Europe. That is great progress, because its concept of lifelong learning is well done and establishes also benchmarks. This is absolutely interesting in comparison with other regions. For us - representing the other areas - European Union is always a model» (Interview 17).

We note a permanent educational interpenetration between the European and the international organisations. We qualified this phenomenon as "governance by source of inspiration» or more appropriately, "competitive governance by ricochet» given that the educational management of one international organisation is influenced by the activities of the other international organisations or by the European Union (Broyon, 2001; Roche, 2001; Moreau Defargues, 2000 ). In the medium or long term, the inspiration could generate a concurrence between the promoting organisations, and for that reason we better named this kind of governance as "competitive governance by source of inspiration». As we can see, there are several steps in the creation of this governance: firstly, there is a sharing of information between organisations, secondly, there is a mutual inspiration and finally, there is a level of «supremacy in lifelong learning governance» - reserved nowadays to the European Union. The following figure summarises this gradation: 


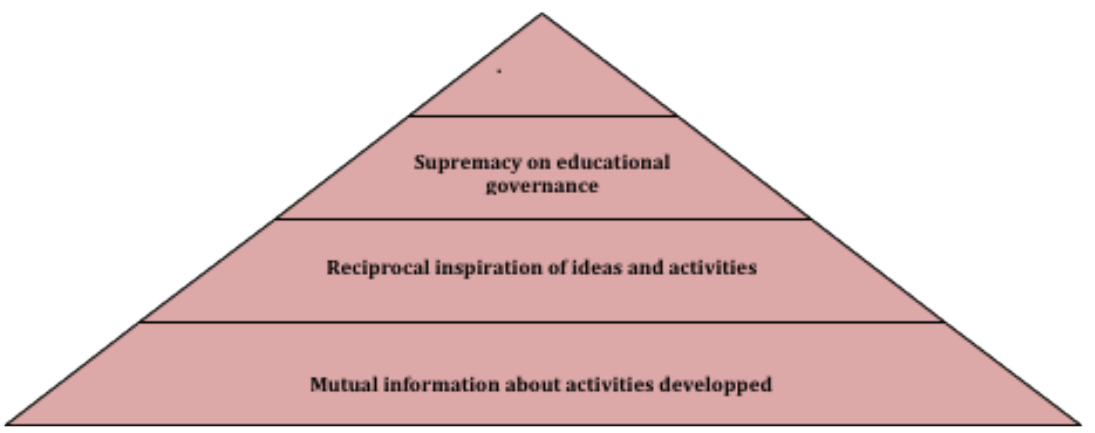

Figure 2: Graduation of "competitive governance by source of inspiration" on lifelong learning policies

\section{Control governance}

A third approach is promoted by international organisations which strongly interact with national policy makers. At an international level, UNESCO represents an emblem of the actors involved in lifelong learning policies. International organisations identify the main directions for educational reforms and make proposals to Member States, namely: "the holistic vision of lifelong learning and of adult education, the reading literacy, the qualifications framework and the accessibility to education and training” (Interview 16). National policy makers are invited to take into account the recommendations of the international «influencers» who are making high level decisions in the field of education. After an analysis of the most urgent educational needs, the next step is the evaluation. Although national policy makers should try to follow these international recommendations, international officials have «identified the guidelines. Years after, we recognised that the results were not good, and we asked Member States not to stop their efforts for developing education. Currently, we want to establish a monitoring system» (Interview 17). For international policy makers, one of the keys of successful cooperation is to attract the attention of the national actors and to involve them in programmes and activities. Furthermore, recommendations do not seem to be «imposed» at a supranational level, because they are usually the results of committee meetings with national experts. Involving national actors in education presumes for the international officials that: "these recommendations are not our recommendations, but the recommendations of the national policy makers» (Interview 5). Apart from this aspect, the presence of national actors in the educational activities promoted by the international organisations brings another benefit. How exactly? It is impossible for international policy makers to know all the elements which characterise the educational landscape in each country. Therefore, the national actors act as a «bridge» or «translator» between the national and the international levels. Moreover, their knowledge on the topic 
may be limited due to their lack of time to engage with the deeper discourses and counter-intuitive arguments. Concretely: «in reality it is very difficult to analyse the situation, given that things must function at school level, at the local level. There is still a gap between what happens at the institutional level and at the decisional level» (Interview 11). To fill this gap, common skills, qualifications or benchmarks are suggested by the European or international institutions, transforming education in a political field (Derouet $\&$ Normand, 2007). These educational tools contribute to mutual translation, depict another path of governance in education and: "make the skills and qualifications more transparent, as the unique currency» (Interview 13). This kind of governance could be called a "monitoringcontrol governance» or "decantation governance» where international and European policy makers try to design a common framework to be adopted by all Member States and «translated» into national measures (Boussaguet \& Jacquot, 2009). As showed in the following figure, control governance may include a strong interaction between international and national policy makers and the implementation of a monitoring system to evaluate the appropriation of international recommendations for creating a «common bridge» between national and international educational actors:

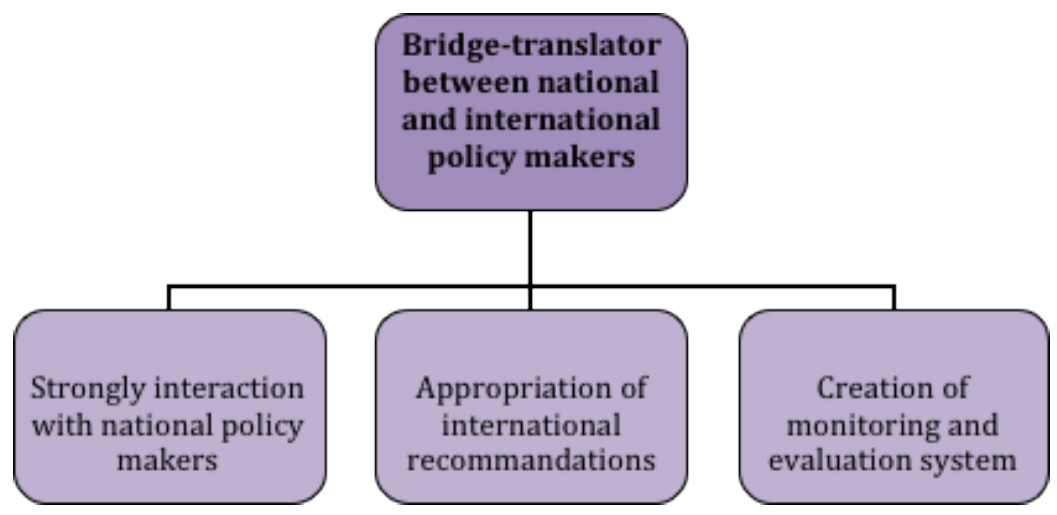

Figure 3: The features of «control governance» in lifelong learning policies

\section{Thematic governance}

Finally, governance in lifelong learning policies is linked to the anticipation of skills needed and to precisely forecast the kind of qualifications required in the future, particularly in the digital era. In the last fifteen years this aspect represented a heated preoccupation of international policy makers: «we saw that there is unsteadiness between the qualifications needed by the labour market and the educational system» (Interview 10). The variation between the two sides, namely educational offers and market demands affects more and more young people who seem to be insufficiently prepared for their future jobs (European Commission, 2009), and a standardised diploma becoming an assessment tool for compe- 
tencies (Aghion \& Cohen, 2004) that are likely to be redundant in the digitised era (OECD, PISA, 2018). Even if international and European mobility is fairly common at academic level, mobility alone cannot palliate the labour market problems faced by young people. Further, we argue that social mobility need not lead to migration of young people from villages to cities causing capacity issues in cities. Thus, social mobility need not lead to geographical mobility that also causes the fragmentation of communities, the breaking up of social networks required for resilience and support, and the propelling of entrepreneurial economies and skills. Finland for example contributes $60.9 \%$ value added through entrepreneurial small and medium enterprises compared to that of the UK's which is 'slightly more than half' as reported in the Annual report on European Small and Medium Enterprises that monitors implementation of the Small Business Act (European Commission, 2018). Finding the balance between a social contract (Taysum, 2019) that promotes personal interests and the social interests ethically is a challenge which is why the European Commission is so committed to empowering small businesses.

Moreover, according to another interlocutor, the transition from school or university to the labour market is interesting, because: «if young people have the chance to find a job before finishing vocational training, they may be less interested in an internship abroad" (Interview 12). In terms of international organisations, education is an indispensable element of the knowledge society. Higher education seems to provide a level where Europeanisation and globalisation are more present and educational governance is more stringent. If we take the example of the higher education level, we may consider that European mobility has been achieved. This mobility process does not come to an end with the European continent, it continues over the whole planet: "At the level of higher education, we can already speak about globalisation linked to mobility and the creation of Erasmus Mundus» (Interview 11). Mobility could provide learners with knowledge, skills and competencies needed on the labour market. This process is identified as «thematic governance» or «sector governance» given that educational management is usually focused on different aspects such as labour market, mobility, skills, competencies or higher education (Kamens \& McNeely, 2009; Lawn \& Grek, 2012). These elements are presented in summary in figure 4 : 


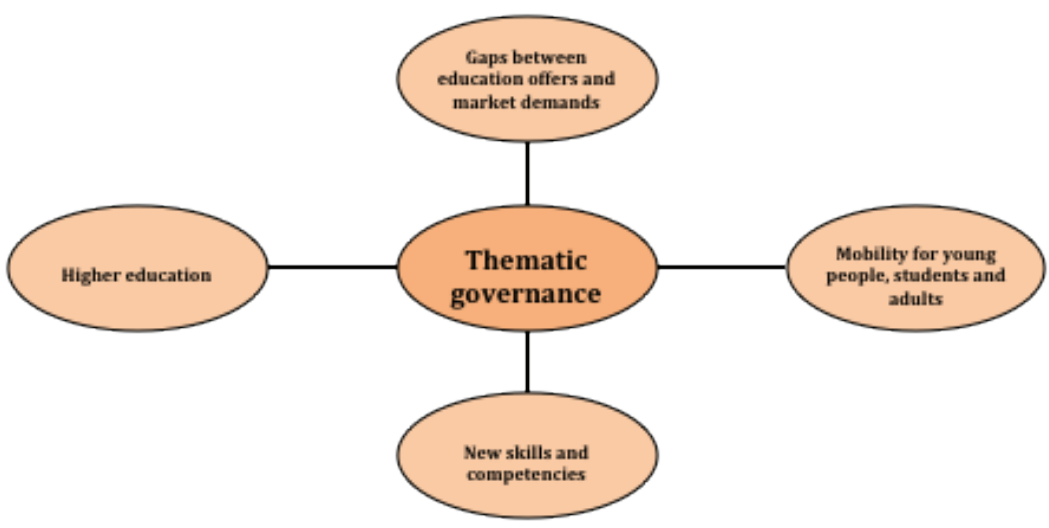

Figure 4: The most current topics of «thematic governance» in lifelong learning policies

To sum up, there is a variety of forms and manifestations of lifelong learning governance promoted by international organisations in terms of discourse analysis and revealed by this practical research. Without claiming an exhaustive character or proposing a hierarchy, the analysis of political discourse based on interviews conducted with international officials reveals this taxonomy of governance in lifelong learning policies and the main features of educational management. To sum up, the four types of governance identified in lifelong learning policies are designated in the following table (Table 2):

Table 2: Taxonomy of governance in lifelong learning policies developed by international organisations

\begin{tabular}{|l|l|}
\hline Taxonomy of governance & Features of governance in lifelong learning policies \\
\hline Collaborative governance & $\begin{array}{l}\text { All international, European and national policy makers are } \\
\text { involved in the decision-making process }\end{array}$ \\
\hline Competitive governance & $\begin{array}{l}\text { Alternatively, an international organisation strongly influences } \\
\text { the other organisations and the Member States }\end{array}$ \\
\hline Control governance & $\begin{array}{l}\text { Each international organisation monitors the changes operated } \\
\text { as a result of internal adaptations }\end{array}$ \\
\hline Thematic governance & $\begin{array}{l}\text { International organisations select a priority theme on which } \\
\text { lifelong learning policies will be focused }\end{array}$ \\
\hline
\end{tabular}

Society changes very quickly nowadays. Implicitly, according to their institutional vision, international organisations promote the implementation of lifelong learning policies in the Member States. A symbiosis between international and national policy makers appears and a kind of «atypical partnership» is installed. According to one of the international interlocutors: «there is a kind of market- 
test that pushes us to make relevant things for countries. For me it is very satisfying, because we know that what we are producing is what our customers - the Member States - want. In my opinion, it is a source of analysis, relevance, energy which signals that something has been more or less appreciated and relevant (Interview 5). In this way, it seems that lifelong learning governance deployed by the international organisations takes the form of an economic partnership which forgets the social dimension of education.

\section{Discussions and perspectives}

Based on the statements of the interlocutors, each level of governance presents several characteristics. Thereby, after crossing the assertions, it emerges that lifelong learning governance is a mixture of the main attributes of international, but also European and national governance. At the same time, every level of governance split into multiple directions.

1. At the international level, the major changes such as the massification of education and the cooperation through education have a social and economic impact on education. For that purpose, a toolbox for expertise, analysis, monitoring and control is being implemented by these organisations. There is a general need to move from this kind of findings into a "so what" approach to elaborate knowledge for action strategies. In this regard, Taysum (2020) is creating a Toolkit for education Policy as a Roadmap to achieving the sustainable development goals addressed to policy makers, professional educators and administrators.

2. At the European level, mutual recognition of the diploma and the European dimension of education constitute major assets for educational harmonisation for the knowledge society in the digitised era. Common diagnostic and mobility programmes focused on learning foreign languages and acquiring transversal skills are the pillar for educative governance. Another key point is represented by monitoring and accountability to inform about improvement, effectiveness and efficiency that operationalises policy memory.

3. At the national level, in spite of higher education which already constitutes the "common place of education», governance on lifelong learning policies depends on the political colours of policy makers and the orientation of the country which is subject to changes in the European chairmanship every six months. Delegated competencies and supranational «sanctions» are also complicated mechanisms in the process.

This interconnection at three levels constitutes a unique way of summarising the discourse analysis concerning the governance on lifelong learning policies, as it results from the international officials and policy-makers interviewed. Represented in a diagram, the findings regarding this interactive governance could be represented as follows (Figure 5): 


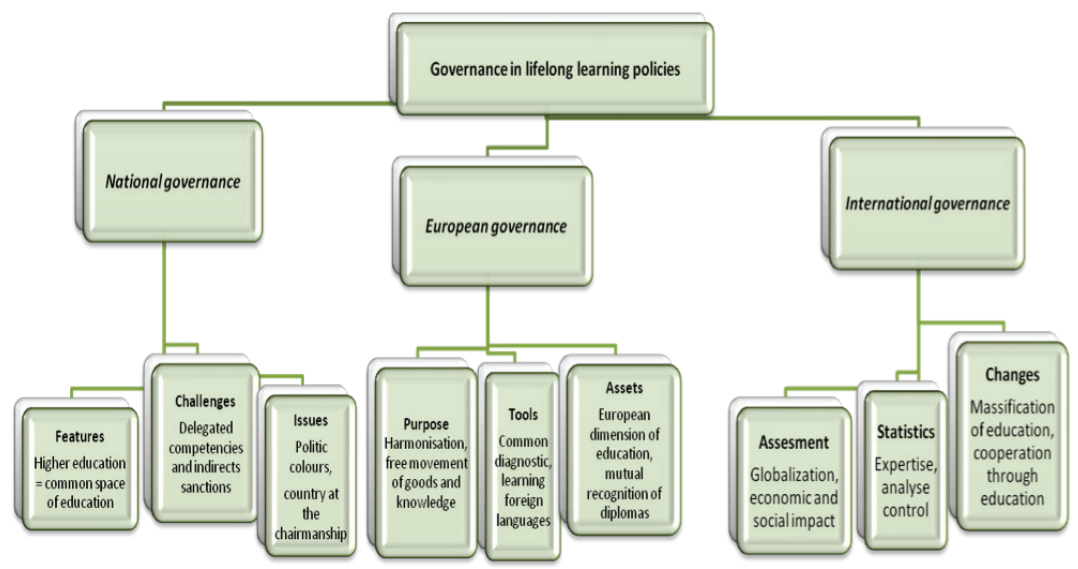

Figure 5: Interactive governance in lifelong learning policies

The purpose of this article was to contribute to the research concerning governance on lifelong learning policies developed by the international organisations. Collaborative or competitive governance as well as control or thematic governance are only multiple facets coated by the current international governance in lifelong learning which may be added to the traditional types of educative governance (Normand, 2016). In this way, our research hypothesis was confirmed. The relevance of the study seems to be important for educators, educational actors and policy makers who need to develop a tenacious consciousness of the different higher leaderships and organisations, influencing the domain in which they and their students work and learn. Thus, our paper adds practical aspects to the scientific dimension, being useful for a diverse range of educational actors interested in new management and governance in lifelong learning policies in the $21^{\text {st }}$ century. A Knowledge to Action strategy is to provide opportunities for workshops for policy actors of our research population to gain deeper understandings than it is possible to gain at biannual conferences. The focus of the workshops are lifelong learning governance and policies as a road map for: a) achieving the Sustainable Development Goals, b) optimising national economic, industrial and small and medium-sized businesses strategies, c) propelling entrepreneurial economies and democracy with critical skills for the digitised era, d) optimising healthy ageing and e) optimising the social and spiritual wealth of citizens.

\section{Notes}

1 Translation from French into English was made by the authors.

2 Translation from French into English was made by the authors. 


\section{References}

Aghion, P., \& Cohen, E. (2004). Éducation et croissance (Rapport avec la collaboration d'Eric Dubois et Jérôme Vandenbussche). La Documentation Française.

Albarello, L. (2003). Apprendre à chercher. L'acteur social et la recherche scientifique 2

( $2^{e}$ éd.). De Boeck Université.

Broyon, M.-A. (2001). L'ERT : État virtuel de l'Union Européenne. In A. Akkari, R. Sultana, \& J.-L. Gurtner (Éds.) Politiques et stratégies éducatives. Terme de l'échange et nouveaux enjeux Nord-Sud. Éditions scientifiques européennes-Peter Lang.

Boussaguet, L., \& Jacquot, S. (2009). Les nouveaux modes de gouvernance. In R. Dehousse (Éd.), Politiques européennes (pp. 409-428). PFNSP.

CEDEFOP. (2008). Terminology of European education and training policy. A selection of 100 key terms. OPOCE.

Cordellier, S. (2005). Le dictionnaire historique et géopolitique du 20e siècle. La Découverte.

Dale, R. (2009). Contexts, contraints and ressources in the development of European Education Space and European Education Policy. In D. Dale, \& S. Robertson (Éds.), Globalization and Europeanization in Education (pp. 7-22). Symposium Books.

De Ketele, J.-M., \& Roegiers, X. (1996). Méthodologie du recueil d'informations. Fondements des méthodes d'observation, de questionnaires, d'interviews et d'études de documents (3e éd.). De Boeck \& Larcier.

Delors, J. (1996). L'éducation: un trésor est caché dedans (Rapport à l'UNESCO de la Commission internationale sur l'éducation pour le vingt-et-unième siècle). UNESCO Publishing.

Delors, J. (2002). L'éducation tout au long de la vie. Défis du vingt-et-unième siècle. Paris, France: UNESCO Publishing.

Dépelteau, F. (2002). La démarche d'une recherche en Sciences Humaines. De la question de départ à la communication des résultats. De Boeck Université.

Derouet, J.-L., \& Normand, R. (2007). L'Europe de l'éducation: entre management et politique. Institut National de Recherche Pédagogique.

European Commission. (2009). De nouvelles compétences pour de nouveaux emplois. Anticiper les compétences requises et adapter l'offre des compétences aux besoins du marché du travail. Luxembourg: OPOCE.

European Commission. (2018). Small and Medium Enterprise Review (a main tool to monitor and assess countries' progress in implementing the Small Business Act). https://ec.europa.eu/ growth/smes/business-friendly-environment/performance-review_en retrieved 03122019

European Union. (2003). Council Conclusions of 5 May 2003 on reference levels of European average performance in education and training (Benchmarks) 2003/C 134/02. OPOCE.

European Union. (2009). Council conclusions of 12 May 2009 on a strategic framework for European cooperation in education and training ('ET 2020') 2009/C 119/02. OPOCE.

Faure, E. (1972). Apprendre à être. UNESCO Fayard.

Grundtvig Programme. (2019). Into-Active Europe. Retrieved from http://www.intoactiveeurope.org/what-is-grundtvig.html

Guittet, A. (2002). L'entretien. Techniques et pratiques. Armand Colin.

ILO. (2004). Recommandation 195 concernant la mise en valeur des ressources humaines: éducation et formation tout au long de la vie. Publications du BIT.

ILO. (2009). Pacte mondial pour l'Emploi. Publications du BIT.

Kamens, D. M., \& McNeely, C. L. (2009). Globalization and the growth of international educational testing and national assessment. Comparative Education Review, 54, 5-25.

Kaufmann, J.-C. (1996). L'entretien compréhensif. Nathan.

Kissinger, H. (1996). Diplomatie. Fayard.

Lawn, M., \& Grek, S. (2012). Europeanizing education: Governing a new policy space. Symposium Books. 
Lessard-Hébert, M. Goyette, G., \& Boutin, G. (1997). La recherche qualitative. Fondements et pratiques. De Boeck Université.

Moreau Defarges, P. (2000). L'ordre mondial (2e éd.). Dalloz-Armand Colin.

Mucchielli, A. (1991). Les méthodes qualitatives. P.U.F.

Normand, R. (2016). The changing epistemic governance of European education. The fabrication of the Homo Academicus Europeanus? Springer.

Nye Jr, J. (2002). The paradox of American Power. Why the world's only superpower can't go it alone. Oxford University Press.

OECD PISA. (2018). Teenagers' career expectations narrowing to limited range of jobs, OECD PISA report finds. http://www.oecd.org/newsroom/teenagers-career-expectationsnarrowing-to-limited-range-of-jobs-oecd-pisa-report-finds.htm

OECD. (1997). Politiques du marché du travail: nouveaux défis. Thème 3: Apprendre à tout âge pour rester employable durant toute sa vie (Document de travail Volume V / $\mathrm{n}^{\circ} 88$ ). Service des publications de l'OCDE.

OECD. (2007). Comprendre l'impact social de l'éducation. Centre pour la recherche et l'innovation dans l'enseignement. Service des publications de l'OCDE.

Pépin, L. (2006). The history of European cooperation in education and training. Europe in the making - an example. OPOCE.

Quivy, R., \& Van Campenhoudt, L. (2006). Manuel de recherche en sciences sociales. Dunod.

Radaelli, C. (2010). Définition de l'européanisation. In L. Boussaguet, S. Jacquot, \& P. Ravinet. (Éds.), Dictionnaire des politiques publiques (p. 248). Fondation nationale des Sciences politiques.

Robert, A., \& Bouillaguet, A. (1997). L'analyse de contenu. P.U.F.

Roche, J.-J. (2001). Théories des relations internationales (4e éd.). Montchrestien.

$\mathrm{Ru}$ itoru, M.-V. (2017). Le droit à l'éducation et les politiques éducatives. L'Union européenne et la Roumanie. Harmattan.

Saurugger, S. (2009). Théories et concepts de l'intégration européenne. Fondation Nationale des Sciences Politiques.

Schemeil, Y. (2012). Introduction à la science politique. Objets, méthodes, résultats. Fondation Nationales des Sciences politiques et Dalloz.

Snyder, F. (2000). The Europeanization of Law: The legal effects of European integration. Hart Publishing.

Taysum, A. (2019). Education Policy as a Road Map to Achieving the Sustainable Development Goals. Emerald.

Taysum, A. (2020). Toolkit for Empowering Young Societal Innovators for Equity and Renewal (EYSIER) Charter Mark Award. Available at https://www.alisontaysum.com/ downloaded 14th April 2020.

Tessier, G. (1993). Pratiques de recherche en Sciences de l'Éducation. Presses Universitaires de Rennes.

Van Zanten, A., \& Rayou, P. (2011). Les 100 mots de l'éducation. P.U.F.

Vorbeck, M. (1969). L'équivalence des diplômes serait un moyen de faciliter le processus d'intégration. Le monde Diplomatique, p. 21. Available at https://www.monde-diplomatique.fr/1969/07/VORBECK/29119

Vorbeck, M. (1970). Equivalences of degrees, diplomas and certificates. Review of the Council for Cultural Cooperation of the Council of Europe, 01/01/1970.

Vorbeck, M. (1973). Promoting Higher education Links in Europe. Educational Exchange, n. 3/1973.

Van der Maren, J.-M. (1995). Méthodes de recherche pour l'éducation. Montréal, Québéc: Presses de l'Université de Montréal \& De Boeck.

Keywords: Lifelong learning policies, educational governance, international organisations, thematic analysis 


\section{Förderung lebenslangen Lernens und internationale Organisationen}

\section{Zusammenfassung}

Lebenslanges Lernen wird von der Bildungspolitik auf unterschiedliche Weise gefördert. Unsere Untersuchungen gehen davon aus, dass die politische Förderung lebenslangen Lernens neue Formen finden muss. Um die Beweiskraft dieses Konzepts zu testen, führte der Erstautor Gespräche mit Beamten und politisch verantwortlichen Vertretern internationaler Organisationen wie der UNESCO, der OECD, der Internationalen Arbeitsorganisation (ILO) und dem Europarat. Die thematische Analyse der Ergebnisse zeigte, dass die Förderung lebenslangen Lernens von einem «spiralenförmigen Effekt» oder von «interaktiven Bemühungen», mithin einer institutionellen Zusammenarbeit gekennzeichnet ist, die sich bei der Entscheidungsfindung internationaler, europäischer und nationaler Gremien ergibt und die Bedingung dafür ist. Gleichzeitig ergab sich ein doppeltes Problem, nämlich die wirtschaftlichen Schwierigkeiten (Beschäftigungsmöglichkeit, Arbeitsplatzsicherheit und Flexibilität, Finanzierbarkeit, Freizügigkeit) sowie das Überprüfungsverfahren (Expertise, Vergleichbarkeit, Übertragbarkeit, Überwachung und Kontrolle), Gesichtspunkte, die gegenüber der gesellschaftlichen Rolle der Bildung Vorrang genießen. Dies ist wichtig, weil es die soziale Rolle der Bildung ist, die es dem Bürger ermöglicht, nationale, regionale und internationale politische Vorhaben Wirklichkeit werden zu lassen und weil es das Überprüfungsverfahren ist, das für nachhaltige Entwicklung sorgt. Die Auswertung der thematischen Analyse der Gesprächsergebnisse zeigt deutlich neue Formen der Förderung lebenslangen Lernens, beruhend auf Zusammenarbeit, Wetteifern um die beste Politik, Kontrolle und thematischen Schwerpunkten. Die Autoren taten sich zusammen, um gemeinsam diese Taxonomie der Förderung lebenslangen Lernens vorzustellen und Empfehlungen zur bestmöglichen Förderung lebenslangen Lernens auszusprechen.

Schlagworte: Bildungspolitik, Lebenslanges Lernen, internationale Organisationen, Thematische Analyse 


\section{La gouvernance de l'apprentissage tout au long de la vie et les organisations internationales}

\section{Résumé}

Les politiques d'éducation tout au long de la vie font l'objet de diverses approches de gouvernance éducative. Dans cette recherche, nous formulons l'hypothèse que les politiques éducatives engendrent de nouvelles facettes de gouvernance. Afin de vérifier cette hypothèse, l'auteur principal a mené des entretiens avec des fonctionnaires et décideurs politiques de différentes organisations internationales, telles que l'Organisation des Nations Unies pour l'éducation, la science et la culture, l'Organisation de Coopération et de Développement Économiques, l'Organisation Internationale du Travail et le Conseil de l'Europe. L'analyse thématique du discours politique révèle que la gouvernance éducative est caractérisée par un " effet de spirale " ou "gouvernance interactive " - un brassage institutionnel qui fonctionne et conditionne la prise de décisions des acteurs internationaux, européens et nationaux. Dans le même temps, un double défi est souligné, à savoir les difficultés économiques (employabilité, flexisécurité, financement et mobilité) et le processus de monitoring (expertise, comparaison, surveillance et contrôle), metteant dans l'ombre l'impact social de l'éducation. Cet aspect est important car, à travers ce rôle social, les citoyennes et citoyens sont formés à réaliser des plans stratégiques au niveau national, régional et international, ainsi que le monitoring du développement durable. L'investigation met en lumière de nouvelles formes de gouvernance en politiques d'éducation tout au long de la vie, à savoir "gouvernance collaborative, gouvernance compétitive, gouvernance par contrôle et gouvernance thématique ". Les auteur.e.s ont collaboré pour présenter le décryptage de cette taxonomie en gouvernance éducative avec des recommandations sur la façon dont on peut optimiser les politiques d'éducation tout au long de la vie.

Mots-clés: Politiques d'éducation tout au long de la vie, gouvernance éducative, organisations internationales, analyse thématique de discours

\section{Governanza nel apprendimento lungo tutto l'arco della vità e le organizzazioni internazionali}

\section{Riassunto}

Le politiche di apprendimento lungo tutto l'arco della vita sono oggetto di vari approcci di governance educativa. La nostra ricerca parte dall'ipotesi che tali politiche stiano creando ed integrando nuovi aspetti della governance. Per testare quest'ipotesi, l'autore principale ha condotto interviste con funzionari e responsabili politici di organizzazioni internazionali come l'Organizzazione 
delle Nazioni Unite per l'istruzione, la scienza e la cultura (UNESCO), l'Organizzazione per la cooperazione e lo sviluppo economico (OCSE), l'Organizzazione internazionale del Lavoro (OIL) e il Consiglio dell'Europa (CoE). L'analisi tematica dei dati ha rilevato che la governance educativa è caratterizzata da un "effetto a spirale» o "governance interattiva» - una formazione istituzionale che funziona e condiziona il processo decisionale di attori internazionali, europei e nazionali. Allo stesso tempo, viene messo in evidenza un doppio esito, vale a dire le difficoltà economiche (occupabilità, flessibilità, sicurezza, finanziamento e mobilità) ed il processo di monitoraggio (consulenza, confronto, recepimento, supervisione e controllo) che hanno la priorità rispetto al ruolo sociale dell'educazione. Ciò è importante perché il ruolo sociale dell'educazione conferisce ai cittadini la realizzazione dei piani strategici a livello nazionale, regionale ed internazionale ed il monitoraggio dello sviluppo sostenibile. L'analisi dei dati mette inoltre in luce evidenze di nuove forme di governance nelle politiche educative, come la "governance collaborativa, governance competitiva, governance di controllo e governance tematica». Gli autori hanno collaborato per presentare questa tassonomia sulla governance di apprendimento permanente con raccomandazioni su come si può ottimizzare l'apprendimento lungo tutto l'arco della vita

Parole-chiave: Politiche di apprendimento lungo tutto l'arco della vità, governanza educativa, organizzazioni internazionali, analisi tematica

\section{Authors}

Mihaela-Viorica Ruşitoru is doctor in Education Sciences in France and in International Relations - European Studies in Romania. She is currently associate researcher at the University of Bourgogne Franche-Comté, Laboratory ELLIADD in France and at the University of Helsinki, in Finland. Specialist in lifelong learning policies developed by the International Organisations, the European Union and the national governments, Mihaela graduated previously in Orthodox Theology-Social Work in Cluj-Napoca as well as in Law, Educational and Political Sciences, Ethics and Human Rights in Strasbourg. She worked at the European Court of Human Rights and at the Council of Europe, currently being Junior Science Officer in charge of doing scientific evaluation of academic projects at the European Science Foundation in Strasbourg. Mihaela did researches in universities in Canada, Finland, France, Romania and United Kingdom and published books in drugs addiction and lifelong learning policies, and articles related to the right to education, the educational policies, the media education, religious education and the gerontagogy. Her latest book addresses the Finnish excellence in Finland.

1, Quai Lezay-Marnésia, F-67100 Strasbourg

E-Mail: mihaela_rusitoru@yahoo.com 
Arto Kallioniemi, Ph.D is Professor of Religious Education at the University of Helsinki. Kallioniemi has specialized in researching Religious Education in multicultural societies. He has published several articles in Religious Education teacher education and Religious Education's task in societies. Furthermore, he also holds UNESCO chair on Values, Dialogue and Human Rights. At the moment, he works as Vice Dean (International Affairs, Societal Interaction and Equality).

Siltavuorenpenger 5, FIN-00170 Helsinki

E-Mail: arto.j.kallioniemi@helsinki.fi

Alison Taysum has been a Principal Investigator for funded and unfunded International research projects since 2005. She was commissioned to give key notes in Japan including the Ministry of Education, Cambridge University, Oxford University, The University of California, and the Indonesian Embassy in London. She leads large symposiums and individual presentations at international conferences Overseas and in Europe. A Senior Fellow of the Higher Education Academy she has delivered a 40-hour doctoral training programme in Kazakhstan and Master lectures in Russia. She is Director Treasurer for BELMAS and leads two funded networks for doctoral and Masters'students. She has served as an Expert Assessor for the European Union and reviews for funding councils including ESF, International peer-reviewed journals, book publishers, International Conferences, the BELMAS Bursary Award Panel and sits on International Peer Reviewed Editorial Boards and Chairs the BELMAS Doctoral Thesis Award Panel. Until December 2019 she was both Director for the Distance Learning MSc in Educational Leadership and supervised PhD students to completion at the University of Leicester. She has held/holds doctoral and Masters level external examiner positions Overseas, in Europe, and in the UK. She is a committed Christian, sings in the church choir.

Society, Spaces Acero, Office G14, 1 Concourse Way, UK-Sheffield, S1 2BJ

E-Mail: ast11@leicester.ac.uk 